NBER WORKING PAPER SERIES

\title{
TESTING ENDOGENOUS GROWTH IN \\ SOUTH KOREA AND TAIWAN
}

\author{
Robert C. Feenstra \\ Dorsati Madani \\ Tzu-Han Yang \\ Chi-Yuan Liang
}

Working Paper 6028

\section{NATIONAL BUREAU OF ECONOMIC RESEARCH \\ 1050 Massachusetts Avenue \\ Cambridge, MA 02138 \\ May 1997}

The authors thank Nicole Biggart, Gary Hamilton, Gordon Hanson, and Dan Huang for helpful comments. This research has been supported by the Pacific Rim Research and Development Program, University of California, Davis. Financial assistance from the Ford Foundation is gratefully acknowledged. This paper is part of NBER's research program in International Trade and Investment. Any opinions expressed are those of the authors and not those of the National Bureau of Economic Research.

(C) 1997 by Robert C. Feenstra, Dorsati Madani, Tzu-Han Yang and Chi-Yuan Liang. All rights reserved. Short sections of text, not to exceed two paragraphs, may be quoted without explicit permission provided that full credit, including $(\mathcal{C}$ notice, is given to the source. 
Testing Endogenous Growth in South Korea

and Taiwan

Robert C. Feenstra, Dorsati Madani, Tzu-Han Yang and Chi-Yuan Liang

NBER Working Paper No. 6028

May 1997

JEL Nos. F14, O47, 053

International Trade and Investment

\begin{abstract}
We evaluate the endogenous growth hypothesis using sectoral data for South Korea and
\end{abstract} Taiwan. Our empirical work relies on a direct measure of the variety of products from each sector which can serve as intermediate inputs or as final goods. We test whether changes in the variety of these inputs, for Taiwan relative to Korea, are correlated with the growth in total factor productivity (TFP) in each sector, again measured in Taiwan relative to Korea. We find that changes in relative product variety (entered as either a lag or a lead) have a positive and significant effect on TFP in eight of the sixteen sectors. Seven out of these eight sectors are what we classify as secondary industries, in that they rely on differentiated manufactured inputs, and therefore seem to fit the idea of endogenous growth. Among the primary industries that rely more heavily on natural resources, we find more inixed evidence.

Robert C. Feenstra

Department of Economics

University of California, Davis

Davis, CA 95616

and NBER

rcfeenstra@ucdavis.edu

Tzu-Han Yang

Council for Economic Development

10th floor, 87, Section 2

Nan-king East Road

Taipei

TAIWAN

tmyang@sun.cepd.gov.tw
Dorsati Madani

International Trade Division

The World Bank

1818 H Street, NW

Washington, DC 20433

dmadani@worldbank.org

Chi-Yuan Liang

Institute of Economics

Academia Sinica

Nankang, Taipei

TAIWAN 11529

cliang@ieas.econ.sinica.edu.tw 


\section{Introduction}

The promise of the endogenous growth models, to explain the diversity of growth rates across countries and time, has so far not materialized. Despite the sophistication of these models, attempts to apply them to country data have met with mixed success. For the industrial countries, Mankiw, Romer and Weil (1992) have argued that the conventional Solow growth model, extended to allow for human capital, provides a quite satisfactory explanation of growth. Jones $(1995 \mathrm{a}, \mathrm{b})$ proposes two direct test of endogenous growth: that changes in either the investment rate or in the scale of resources devoted to research and development (R\&D) should affect the growth rate. Both of these hypotheses are decisively rejected on data for the U.S. and other advanced countries. The volume by Ito and Krueger (1995) contains evaluations of growth models applied to newly-industrialized countries, and even in these papers, there is a wide range of opinions on the sources of growth in these countries. ${ }^{1}$ Ito and Krueger conclude that: "Clearly a great deal more research, especially on the microeconomic aspects of growth, will be required before the avenues by which rapid growth occurs are reasonably well understood" (p. 5). This paper will present one micro-based test of the determinants of growth.

In rejecting the endogenous growth models, Jones (1995a,b) suggest an alternative that he calls "semi-endogenous" growth. In this formulation, growth occurs due to the development of new intermediate inputs by forward-looking firms, as in the models of Romer (1990) and Grossman and Helpman (1991). In order to generate steady-state growth in the absence of endowment increases, these authors relied on the assumption that the R\&D costs of creating new

\footnotetext{
${ }^{1}$ For example, Fukuda and Toya (1995) finds support for conditional convergence among the East Asian countries, once the differing shares of exports is controlled for, whereas Easterly (1995) argues that the rapid growth of the Asian "tigers" is not accounted for by cross-country convergence regressions. Of course, this difference of opinion on one narrow question reflects a much wider divergence of views on whether the Asian growth experience is unique at all: compare the World Bank (1993) and Krugman (1994).
} 
intermediate inputs are inversely proportional to the number of existing inputs. This assumption leads to the result that an increase in the scale of resources devoted to $R \& D$ will increase the growth rate; a result that Jones rejects. He suggests an alternative whereby the R\&D costs still decline when more inputs are invented, but at a slower pace. In this case, the "scale effect" of $R \& D$ on the growth rate does not arise, though growth still occurs due to the development of new intermediate inputs. It is this link between new intermediate inputs (or new outputs) and growth that we shall test in this paper.

We will evaluate the "semi-endogenous" growth model using sectoral data for South Korea and Taiwan. Our empirical work relies on a direct measure of the variety of products from each sector, which can serve as intermediate inputs or as final goods. We shall test whether changes in the variety of these inputs, for Taiwan relative to Korea, are correlated with the growth in total factor productivity (TFP) in each sector, again measured in Taiwan relative to Korea. It seems to us that this is the most direct test of "semi-endogenous" growth, and it is worth asking why it has not been implemented before.

The answer seems to be that the disaggregate data necessary to construct measure of product variety is difficult to obtain, and also perhaps that the method of construction is not well understood. The measure of product variety we shall use is exact for an underlying CES aggregator function, as described in Feenstra (1994) and Feenstra and Markusen (1994), and is reviewed in section 2. The data used to measure product variety from South Korea and Taiwan are the disaggregate exports from these countries to the United States, as also utilized by Feenstra, Hamilton and Yang (1997), and are described in section 3. While is would be preferable to use national production data from these countries, it is not available at a sufficiently disaggregate level. The data on total factor productivity for South Korea are taken from Zeile 
(1993) and Madani (1996,1997), who construct TFP for a panel of 52 industries. Here they are aggregated into sixteen sectors, to match the productivity data for Taiwan, taken from Liang (1989) and Jorgenson and Liang (1995).

Using these rather disparate data sources, in section 4 we analyze the relationship between changes in product variety and the growth in total factor productivity (TFP) across the two countries, in sixteen sectors over 1975-1991. Our results lend support to the "semiendogenous" growth models. We find that changes in relative product variety (entered as either a lag or a lead) have a positive and significant effect on TFP in eight of the sixteen sectors. Seven out of these eight sectors are what we classify as secondary industries, in that they rely on differentiated manufactured inputs, and therefore seem to fit the idea of endogenous growth. Among the primary industries, that rely more heavily on natural resources, we find quite mixed evidence: the correlation between product variety and productivity can be positive, negative, or insignificant. There are only two secondary industries where we fail to find a positive correlation between product variety and productivity, and these are electrical products and transportation equipment, which may be measured at too aggregate a level.

In sum, the sectoral regressions provide some degree of confirmation for the link between product variety and productivity, which is all the more surprising because these two variables are obtained from completely different data sets, so there is no possibility of correlation due to common trends as might arise among macroeconomic variables. These results are preserved when we correct TFP for the possible mismeasurement of the capital share due to imperfect competition, as recommended by Hall $(1988,1990)$, and also when we include the extent of imports or exports in each sector as control variables. In section 5 we discuss the application of our methods to other East Asian countries, and present our conclusions. 


\section{Measuring Product Variety}

\section{A. Time-Series}

The endogenous growth models that rely on an increasing range of intermediate inputs (such as Romer, 1990, and Grossman and Helpman, 1991, chap. 3), generally assume a CES production function defined over these inputs. A theoretical simplification is that all the inputs enter the production function symmetrically, in which case the number of inputs fully summarizes the information about variety. In empirical work this assumption is unacceptable, because some inputs may be more important than others, and any measure of product variety should take this into account. Feenstra (1994) and Feenstra and Markusen (1994) should how an exact measure of product variety can be constructed for a CES production function even when the inputs enter non-symmetrically, and we begin by reviewing these results.

We will consider two units of observation denoted by s and t. In this section we will think of them as successive points in time, but in the next section will treat them as two countries. Suppose that output $\mathrm{y}_{\mathrm{t}}$ in period $\mathrm{t}$ is given by the production function:

$$
y_{t}=f\left(x_{t}, I_{t}\right)=\left[\sum_{i \in I_{t}} a_{i} x_{i t}^{(\sigma-1) / \sigma}\right]^{\sigma /(\sigma-1)},
$$

where $\sigma>1$ is elasticity of substitution, $x_{i t}$ is the quantity of input $i$ in period $t$, and the set of inputs available is denoted by $I_{t}$. For example, if the inputs are numbered 1 through $N_{t}$, then $\mathrm{I}_{\mathrm{t}}=\left\{1, \ldots, \mathrm{N}_{\mathrm{t}}\right\}$. The corresponding cost of producing one unit of $\mathrm{y}_{\mathrm{t}}$ is: 


$$
c\left(p_{t}, I_{t}\right)=\left[\sum_{i \in I_{t}} b_{i} p_{i t}^{1-\sigma}\right]^{1 /(1-\sigma)}, \quad b_{i}=a_{i}^{\sigma},
$$

where $p_{i t}$ are the prices of the inputs $i \in I_{\mathbf{i}}$.

As usual, we define total factor productivity (TFP) as the difference between the growth of output and an index of the inputs. A common measure of an input index is the change in nominal expenditure $\left(E_{t} / E_{s}\right)$ deflated by an input price index, where $E_{t}=\sum_{i \in I_{t}} p_{i t} x_{i t}$. We will suppose that this deflator is constructed by ignoring any change in set of inputs available. Thus, letting $\mathrm{I}=\mathrm{I}_{\mathrm{s}} \cap \mathrm{I}_{\mathrm{t}}$ denote the set of goods common to both periods, we will suppose that the input price index is given by the Sato (1976)-Vartia (1976) formula,

$$
\mathrm{P}\left(\mathrm{p}_{\mathrm{s}}, \mathrm{x}_{\mathrm{s}}, \mathrm{p}_{\mathrm{t}}, \mathrm{x}_{\mathrm{t}}, \mathrm{I}\right) \equiv \prod_{\text {i } \mathrm{II}}\left(\mathrm{p}_{\mathrm{it}} / \mathrm{p}_{\text {is }}\right)^{\mathrm{w}_{\mathrm{i}}(\mathrm{I})}
$$

where the weights $\mathrm{w}_{\mathrm{i}}(\mathrm{I})$ are constructed from the expenditure shares $\mathrm{e}_{\mathrm{it}}(\mathrm{I}) \equiv \mathrm{p}_{\mathrm{it}} \mathrm{x}_{\mathrm{it}} / \sum_{\mathrm{i} \varepsilon \mathrm{I}} \mathrm{p}_{\mathrm{it}} \mathrm{x}_{\mathrm{it}}$ as,

$$
w_{i}(I) \equiv\left(\frac{e_{i t}(I)-e_{i s}(I)}{\ln e_{i t}(I)-\ln e_{i s}(I)}\right) / \sum_{i \varepsilon I}\left(\frac{e_{i t}(I)-e_{i s}(I)}{\ln e_{i t}-\ln e_{i s}(I)}\right) .
$$

The numerator on the right of ( $3 b)$ is a logarithmic mean of the expenditure shares $\mathrm{e}_{\mathrm{it}}$ and $\mathrm{e}_{\mathrm{is}}$, and lies between these two values. The denominator ensures that the weight $\mathrm{w}_{\mathrm{i}}(\mathrm{I})$ sum to unity, so that the Sato-Vartia index is simply a geometric mean of the price ratios $\left(\mathrm{p}_{\mathrm{i}} / \mathrm{p}_{\mathrm{is}}\right)$. This index is exact for the CES unit-cost function in (2) when the range of inputs in held constant, 
meaning that $\mathrm{P}\left(\mathrm{p}_{\mathrm{s}}, \mathrm{x}_{\mathrm{s}}, \mathrm{p}_{\mathrm{t}}, \mathrm{x}_{\mathrm{t}}, \mathrm{I}\right)=\mathrm{c}\left(\mathrm{p}_{\mathrm{s}}, \mathrm{I}\right) / \mathrm{c}\left(\mathrm{p}_{\mathrm{t}}, \mathrm{I}\right)$ provided that the inputs $\mathrm{x}_{\mathrm{s}}$ and $\mathrm{x}_{\mathrm{t}}$ are cost minimizing for the prices $\mathrm{p}_{\mathrm{s}}$ and $\mathrm{p}_{\mathrm{t}}$, respectively.

Making use of this price index, the quantity index for intermediate inputs is measured by:

$$
\widetilde{Q}\left(p_{s}, x_{s}, p_{t}, x_{t}\right)=\frac{E_{t} / E_{s}}{P\left(p_{s}, x_{s}, p_{t}, x_{t}, I\right)}
$$

Total factor productivity is defined as the difference between the growth of output and this input index, $\mathrm{TFP}_{s t}=\ln \left(\mathrm{y}_{\mathrm{t}} / \mathrm{y}_{\mathrm{s}}\right)-\tilde{\mathrm{Q}}\left(\mathrm{p}_{\mathrm{s}}, \mathrm{x}_{\mathrm{s}}, \mathrm{p}_{\mathrm{t}}, \mathrm{x}_{\mathrm{t}}\right)$, which can be simplified as follows:

$$
\begin{aligned}
\mathrm{TFP}_{\mathrm{st}} & =\ln \left(\frac{\mathrm{y}_{\mathrm{t}}}{\mathrm{y}_{\mathrm{s}}}\right)-\ln \left(\frac{\mathrm{E}_{\mathrm{t}} / \mathrm{E}_{\mathrm{s}}}{\mathrm{P}\left(\mathrm{p}_{\mathrm{s}}, \mathrm{x}_{\mathrm{s}}, \mathrm{p}_{\mathrm{t}}, \mathrm{x}_{\mathrm{t}}, \mathrm{I}\right)}\right) \\
& =-\ln \left(\frac{\mathrm{c}\left(\mathrm{p}_{\mathrm{t}}, \mathrm{I}_{\mathrm{t}}\right) / \mathrm{c}\left(\mathrm{p}_{\mathrm{s}}, \mathrm{I}_{\mathrm{s}}\right)}{\mathrm{P}\left(\mathrm{p}_{\mathrm{s}}, \mathrm{x}_{\mathrm{s}}, \mathrm{p}_{\mathrm{t}}, \mathrm{x}_{\mathrm{t}}, \mathrm{I}\right)}\right) \\
& =\frac{1}{(\sigma-1)} \Delta \mathrm{VAR}_{\mathrm{st}},
\end{aligned}
$$

where the change in input variety is defined as,

$$
\Delta \mathrm{VAR}_{\mathrm{st}}=\ln \left(\frac{\sum_{\mathrm{i} \in \mathrm{I}_{\mathrm{t}}} \mathrm{p}_{\mathrm{it}} \mathrm{x}_{\mathrm{it}} / \sum_{\mathrm{i} \in \mathrm{I}} \mathrm{p}_{\mathrm{it}} \mathrm{x}_{\mathrm{it}}}{\sum_{\mathrm{i} \in \mathrm{I}_{\mathrm{s}}} \mathrm{p}_{\mathrm{is}} \mathrm{x}_{\mathrm{is}} / \sum_{\mathrm{i} \in \mathrm{I}} \mathrm{p}_{\mathrm{is}} \mathrm{x}_{\mathrm{is}}}\right) .
$$

Line (4) follows from the definition of the quantity index for inputs, while line (5) is obtained because input expenditure is $\mathrm{E}_{\mathrm{t}}=\mathrm{y}_{\mathrm{t}} \mathrm{c}\left(\mathrm{p}_{\mathrm{t}}, \mathrm{I}_{\mathrm{t}}\right)$, and similarly for period s. Line (6) then follows from Feenstra (1994, Proposition 1), with the definition of product variety in (7). 
To interpret this result, consider the case where the set of inputs is growing, and denote these sets by $I_{s}=\left\{1, \ldots, N_{s}\right\}$ and $I_{t}=\left\{1, \ldots, N_{t}\right\}$, with $N_{t}>N_{s}$. Then the common set of inputs supplied in both periods is $\mathrm{I}=\mathrm{I}_{\mathrm{S}}$, and the denominator of (7) is unity. The numerator will exceed unity, indicating that product variety has increased. In the case where all inputs enter the production and unit-cost functions symmetrically, $a_{\mathrm{i}}=\mathrm{a}_{\mathrm{j}}$, then expenditure on each input is identical, and the numerator in (7) is simply $\mathrm{N}_{\mathrm{t}} / \mathrm{N}_{\mathrm{s}}>1$, reflecting the growth in the number of inputs. Even without the symmetry assumption, (7) shows that it is still possible to construct an exact measure of product variety for the CES case. Then from (6), we see that this measure of product variety is correlated with TFP.

The coefficient on VAR in (6), $1 /(\sigma-1)$, reflects the degree of substitution between new and existing inputs, and is higher when the new inputs are more differentiated from existing ones. The impact of a single new input on productivity is illustrated in Figure 1, which shows the isoquants for the CES production function in (1). With $\sigma>1$, these isoquants touch the axis, with slope of zero or infinity. Initially suppose that only $\mathrm{x}_{1}$ is available, so that with a total expenditure illustrated by the line $\mathrm{AB}$, the firm would purchase the amount shown at $\mathrm{A}$. Output is then $\mathrm{y}_{1}$. When the second input $\mathrm{x}_{2}$ is also available, then at the same level of expenditure the firm can hire the two inputs at the point $\mathrm{C}$, and obtain the higher level of output $\mathrm{y}_{2}$. Since expenditure has not changed, TFP will simply equal the ratio $\left(y_{2} / y_{1}\right)$, the magnitude of which depends on the degree of convexity of the isoquants, or the value of $\sigma$.

While we have so far focused on the case of new inputs, it is worth noting that our analysis applies equally well to new outputs. To model this, suppose that we reinterpret (1) as a 
transformation function between the vector of output varieties $x_{t}$, and the scalar measure of resources $y_{t}$ needed to produce these outputs. In this case we consider values of $\sigma<0$, so that for a given level of resources $y_{t}$ the transformation curve between the outputs $x_{1}$ and $x_{2}$ is illustrated in Figure 2. If initially only the first output $\mathrm{x}_{1}$ is feasible to manufacture, then production would occur at $\mathrm{A}$, and the value of production is represented by the budget line $\mathrm{AB}$. If then the second output $\mathrm{x}_{2}$ becomes feasible, with the same level of resources production would move to point $\mathrm{C}$, and the value of production (represented by the budget line) has clearly increased. In this case TFP should be defined as the negative of (4), that is, the growth in real output less the growth in the scalar input $y_{t}$. Then the expansion of output varieties would imply a growth in TFP, which is precisely correlated with the measure of output variety in (7): $\mathrm{TFP}_{s t}=-\Delta \mathrm{VAR} /(\sigma-1)>0$, since $\sigma<0$ and $\triangle \mathrm{VAR}>0$ due to the new outputs.

\section{B. Panel Data}

Our discussion above was aimed at developing a measure of changes in product variety that applies over time. But it can be equally important to compare the level of product variety across countries, for example, across South Korea and Taiwan in any given year. Given comparable data on the inputs used across countries, and on their outputs, our results above can be re-interpreted as a cross-sectional comparison. Thus, suppose that the production function in (1) applies to either a South Korean industry (denoted by s) or the same industry in Taiwan (denoted by t). Then $\mathrm{TFP}_{\mathrm{st}}$ in (6) represents the comparative productivity level of the Taiwanese relative to the Korean industry. The product variety measure in (7) would reflect the comparative 
input or output variety in Taiwan relative to Korea. A relatively higher level of variety in Taiwan, for example, would imply a higher level of productivity in that country.

We will also want to compare the level or change in product variety across countries and over time. For the cross-sectional variety index, we should choose the set of common goods I as the intersection of product supplied by each county in any year, but for a time-series index, we should choose the set I as the intersection of products supplied by any single country over two adjoining years. We will satisfy both these criterion by specifying the set $\mathrm{I}$ as the intersection of products supplied by both Korea and Taiwan in two adjoining years. To specify this more formally, let us denote the years by $\tau$, while $s$ and $t$ still denote the countries. Then let $\mathrm{I}_{\tau} \equiv \mathrm{I}_{\mathrm{t} \tau} \cap \mathrm{I}_{\mathrm{s} \tau}$ denote the set of goods supplied by both Taiwan and Korea in year $\tau$, while $\mathrm{I} \equiv \mathrm{I}_{\tau-1} \cap \mathrm{I}_{\tau}$ denotes the common goods in both years $\tau-1$ and $\tau$, across both the countries. The change in product variety in Taiwan relative to South Korea can then be expressed as:

$$
\Delta \operatorname{VAR}_{\tau}=\left[\ln \left(\frac{\sum_{i \in I_{t \tau}} p_{i t} x_{i t \tau} / \sum_{i \in I} p_{i t \tau} x_{i t \tau}}{\sum_{i \in I_{s}} p_{i s} x_{i s} x_{i s} / \sum_{i \in I} p_{i s} x_{i s \tau}}\right)-\ln \left(\frac{\sum_{i \in I_{t \tau-1}} p_{i t \tau-1} x_{i t \tau-1} / \sum_{i \in I} p_{i t \tau-1} x_{i t \tau-1}}{\sum_{i \in I_{s \tau-1}} p_{i s \tau-1} x_{i s \tau-1} / \sum_{i \in I} p_{i s \tau-1} x_{i s \tau-1}}\right)\right]
$$

This change in relative product variety can be viewed as the difference between the crosssectional product variety indexes computed in years $\tau$ and $\tau-1$, or alternatively, as the difference between the time-series change in product variety for Taiwan and Korea. So long as the set of common goods I is consistently chosen as the intersection of goods produced in both countries across both years, then these interpretations are equivalent. Expression (8) measures the change in product variety in Taiwan relative to Korea, which we will take as a potential determinant of the growth of total factor productivity across the two countries. 


\section{Data and Estimating Equation}

To contrast the product variety of South Korea and Taiwan, we will use disaggregate U.S. import statistics for 1972-1991. That is, we will be measuring the product variety of these countries using data on their exports to the U.S. It would be preferable to instead use industrial production data for each country to measure input variety, but such data are not available (to us) at the same level of disaggregation as the trade data. ${ }^{2}$ Since the U.S. is the largest destination market for both countries (more than $30 \%$ of Korean exports and $40 \%$ of Taiwanese exports came into the U.S. in the last decade) their performances in this market should reflect the features of their production quite well. Nevertheless, our use of export data to measure product variety has two key limitations.

First, the variety of inputs from one country are in principle available to other countries through trade, so that productivity in each country does not depend on only the export variety from the same country: it would also depend on the matrix of export varieties from all of its trading partners. We do not have the data to trace through these linkages, however, and will simply correlate the relative export variety from Taiwan and South Korea on their relative productivities. Ignoring the intermediate inputs available to each country from other sources is clearly a limitation of our approach. ${ }^{3}$

Second, even after a new input is created domestically, it may take some time before it is exported to the United States. If the new input has an immediate impact on productivity, but

2 It is possible that industrial census data for any country is collected at the same level of disaggregation at trade statistics, but census data is not generally collected annually. Rather than using the U.S. import data, it would still be preferable to use the world-wide export data from each country, if it were available on the highly disaggregate harmonized commodity system, allowing comparability across countries. Our use of the U.S. import data is due to the ready accessibility of this data, as described in Feenstra (1996).

3 On the other hand, if instead we interpret our measure of product variety as measuring the varieties of outputs, then restricting ourselves to measuring the product variety from each country seems more appropriate. 
there is a lag before it is exported, this means that productivity will be correlated with the product variety of export in the future. In other words, we should consider lead values of product variety as a determinant of productivity. Conversely, if the new input is exported quickly, but it takes some time for its appearance to influence productivity, then we would expect lag values of product variety to be a determinant of productivity. These considerations can be taken into account by allowing a flexible pattern of timing between the leads or lags of product variety, and productivity. We will introduce this structure into our estimating equation.

The industries we will use to evaluate the relation between product variety and productivity are similar to the two-digit Standard Industrial Classification industries in the U.S., excluding petroleum, and are listed in Table 1 along with their SIC numbers. We have divided these into two broad groups of primary and secondary products. The primary products are meant to use mainly non-differentiated, natural resources as intermediate inputs. The secondary products are meant to use both raw materials and manufactured inputs, and also be more complex in their production process. There are obviously some ambiguous cases, such as: paper and printing, which includes both the primary sector pulp and paper (SIC 26) and secondary sector printing and publishing (SIC 27); and also chemicals and plastics (SIC 28), which we have classified as a secondary sector though it includes some primary products. While the classification between primary and secondary industries is somewhat arbitrary, it will be useful as a way to summarize our results. In particular, we would expect the hypothesis of "semiendogenous" growth to apply more to the secondary than the primary industries.

Turning to the data, for 1972-1988 the U.S. import statistics distinguish commodities from each country according to their 7-digit Tariff Schedule of the United States (TSUSA) numbers, that number over 10,000 each year; for later years the commodities are classified 
according to the 10-digit Harmonized System (HS), that distinguishes even a larger number of commodities. In order to measure the product variety of U.S. imports from Taiwan (denoted by t) relative to South Korea (denoted by s), we construct indexes of product variety for each year in our sample period. In the first column of Table 1 we report the average level of product variety over 1972-1991 in Taiwan relative to South Korea, which is constructed as a cross-sectional index of product variety in the two countries for each year (as in eq. (7), multiplied by 100). Positive (negative) values for this index indicate higher product variety in Taiwan (Korea). We see that Taiwan has greater product variety than Korea in a number of industries, with the principal exceptions of basic metals and transportation equipment, and several other industries that have indexes near zero. This confirms the same result found for a more limited time period and using slightly different methods in Feenstra, Huang and Hamilton (1997). ${ }^{4}$ Indeed, it was the realization that the product variety of exports from these countries were measurably different that provided the motivation for the present study.

After taking first differences our sample period becomes 1973-1991, and in the second column of Table 1 we report the average over this period of the change in the product varieties, for Taiwan relative to Korea (constructed as in (8) and multiplied by 100). Despite the relatively small values for these average changes over the sample, the year-to-year values for (8) can be quite substantial. The data for the change in relative product varieties, constructed as in (8) and multiplied by 100 , are illustrated by the dashed lines in Figures $3-18$, which are graphed relative to the right-hand side scales in each Figure. We illustrate both the annual values for $\Delta \mathrm{VAR}_{\tau}$ in

4 These authors measure product variety at a more disaggregate level than the two-digit sectors in Table 1, and only for 1978-1988. They attribute the greater product variety of Taiwan relative to South Korea as arising from the differing structure of business groups in the two countries: Korea has much larger and more vertically-integrated business groups than Taiwan, which are apparently focusing on a narrower range of product varieties. This outcome is predicted from the theoretical model developed in Feenstra, Yang and Hamilton (1997). 
(8), and in some cases, these same values shifted as a lag or a lead. The use of these shifted values will be explained below.

The data on total factor productivity for South Korea are taken from Zeile (1993) and Madani $(1996,1997)$, who construct TFP for a panel of 52 industries. Here they are aggregated into sixteen sectors, to match the productivity data for Taiwan, taken from Liang (1989) and Jorgenson and Liang (1995). For both countries TFP is measured as a Divisia (or Tornqvist) index, namely, the rate of growth of output minus a weighted average of the growth of inputs, where the weights are average of the expenditure shares on the inputs in the two years. The inputs included intermediate goods (aggregated from the input-output tables), energy, labor, and several kinds of capital. In Table 1 we show the average growth of TFP for each of the countries over the sixteen industries, where for convenience we have multiplied each annual change by 100 , so the growth rates are in percent. In the last column, we show the difference between the TFP growth rate in Taiwan and South Korea. This difference in the growth rates across the two countries for each industry $\mathrm{k}$ and year $\tau$ is denoted by $\mathrm{TFP}_{\mathrm{k} \tau}$, and will be the dependent variable in our estimating equation. This dependent variable is graphed as the solid line in Figures 3-18, which is measured relative to the left-hand scale in each Figure.

We shall estimate the relation between TFP and product variety as,

$$
\mathrm{TFP}_{\mathrm{k} \tau}=\alpha_{\mathrm{k}}+\beta_{\mathrm{k}} \mathrm{Year} 81+\gamma_{\mathrm{k}} \Delta \mathrm{VAR}_{\mathrm{k} \tau-\ell}+\varepsilon_{\mathrm{k} \tau}
$$

where $\alpha_{k}$ is a constant term for each industry $\mathrm{k}$, and $\beta_{\mathrm{k}}$ is the estimated impact of the 1981 depreciation of the New Taiwan dollar, which will be significant for a number of industries. ${ }^{5}$

5 The New Taiwan dollar began a large depreciation in 1981, after several years of stability since it was floated in 1978. In addition to this dummy-variable, we also considered including a time-trend in (9), but found that it was 
The change in relative product variety across the two countries - adjusted for the lag or lead denoted by $\ell-$ is used as explanatory variable for the difference in the growth of TFP across the countries. This is the specification consistent with the "semi-endogenous" growth equation in (6), from which we see that the coefficient $\gamma_{\mathrm{k}}$ equals $1 /\left(\sigma_{\mathrm{k}}-1\right)$, where $\sigma_{\mathrm{k}}$ is the elasticity of substitution between differentiated inputs in industry $\mathrm{k}$. We will experiment with using either lead or lagged values for the change in relative product variety, since as argued above, there may be time taken to export products time taken for new inputs to influence productivity. Including both leads and lags creates too much multi-collinearity, and the results are difficult to interpret. Instead, we shall use the Akaike information criterion to select the best (single) value of $\ell$ from among the annual values $\{-2,-1,0,1,2\}$.

It should be noted that in (9) we are correlating the growth rate of TFP with the change in product variety in the same industry, rather than in the upstream supplying industries. Our reason for this is twofold: (i) at the two-digit level we are dealing with, the most important supplying industries are often in the same two-digit sector, so that changes in product variety in each sector will partly reflect new inputs used in that sector; (ii) changes in product variety will also reflect new outputs, which will be correlated with productivity in that sector (from our discussion at the end of section $2 \mathrm{~A})$.

The error term in (9) reflects all other factors that would influence TFP across the industries and countries. One of these is the presence of imperfect competition and pure profits. As argued by Hall $(1988,1990)$, in the presence of pure profits the capital share would be overstated, and therefore potentially bias the measure of TFP. To see this, recall that TFP is 
measured as the difference between the growth in output and a share-weighted average of the growth in inputs. If the capital share is overstated, this will have an impact on TFP whenever capital is growing at a different rate from the other inputs. Thus, the correction proposed by Hall is to regress TFP on a variable that is the difference between the growth of capital and the growth of the other inputs, averaged over those inputs.

An alternative suggested by Domowitz, Hubbard and Petersen (1988), as we shall follow, is to use the difference between output growth and capital growth in each industry as an additional regressor. We will denote this variable by $\mathrm{X}_{\mathrm{k} \tau}$, which is measured as a difference between Taiwan and South Korea, and is included on the right of (8):

$$
\mathrm{TFP}_{\mathrm{k} \tau}=\alpha_{\mathrm{k}}+\beta_{\mathrm{k}} \mathrm{Year} 81+\gamma_{\mathrm{k}} \Delta \mathrm{VAR}_{\mathrm{k} \tau-\ell}+\delta_{\mathrm{k}} \mathrm{X}_{\mathrm{k} \tau}+\varepsilon_{\mathrm{k} \tau}
$$

The industry-specific estimate on $\mathrm{X}_{\mathrm{k} \tau}$ is interpreted as $\delta_{\mathrm{k}}=\left(\mu_{\mathrm{k}}-1\right)$, where $\mu_{\mathrm{k}}$ is the price-cost ratio in each industry. The variable $\mathrm{X}_{\mathrm{k} \tau}$ clearly needs to be treated as endogenous, since it is constructed from the same data used to construct $\mathrm{TFP}_{\mathrm{k} \tau}$, so that (9) will be estimated using instrumental variables. The instruments used are growth in manufacturing level nominal and the change in manufacturing sector wholesale price indices for South Korea and Taiwan, as well as a lagged value of $X_{k \tau}$. In addition, we shall experiment with including additional control variables in (9), such as the level of imports and exports. ${ }^{6}$

\footnotetext{
${ }^{6}$ The instruments were obtained from the same sources as the TFP data. We also experimented with using the growth of apparent consumption for all manufacturing, and the change in national exchange rates, as alternative instrumental variables. These gave similar overall results, though they do not provide as good a fit in the first-stage regressions. The import and export series come from the Economic Statistics Yearbook of the Republic of Korea, and the Taiwan Statistical Data Book
} 


\section{Estimation Results}

Table 2 reports the Akaike information criterion from regression (9) run on each sector, where we consider one or two-year leads or lags of the product variety variable. This criterion adjusts the sum of squares residuals from each regression to account for differing numbers of observations, and can be used as a basis for model selection. ${ }^{7}$ We have computed this criterion for the regressions run over 1973-1991, and also over 1975-1991; the latter results are more stable, due to the erratic movements in TFP for some sectors in the early years. According, in Table 2 and all following results we use the 1975-1991 sample, though similar results are obtained when we include the earlier years.

The minimum values of the Akaike information criterion for each industry are shown in bold in Table 2. There are several industries where a unique minimum values does not occur: in clothing and apparel, the minimum is obtained with either a two-year lag or a two-year lead of product variety; while for electronic products, and transportation equipment, the criterion is at a minimum for a zero, one, or two-year lag. The latter industries are cases where product variety is essential unrelated to productivity, as we shall report below. We chose the lag or lead for product variety that minimizes the Akaike information criterion shown in Table 2, and then report these industry regressions (9) in full in Table 3, estimated with ordinary least squares. ${ }^{8}$

Of principal interest in Table 3 is the coefficient $\gamma_{\mathrm{k}}$ on the change in relative product variety between Taiwan and South Korea, as shown in the second column. This coefficient equals $1 /\left(\sigma_{\mathrm{k}}-1\right)$, where $\sigma_{\mathrm{k}}$ is the elasticity of substitution between the differentiated inputs in

\footnotetext{
${ }^{7}$ The Akaike information criterion equals $\ln (\mathrm{SSR} / \mathrm{N})+(2 \mathrm{~K} / \mathrm{N})$, where $\mathrm{SSR}$ is the sum of squared residuals, $\mathrm{N}$ is the number of observations, and $\mathrm{K}$ is the number of estimated coefficients.
} 
industry $\mathrm{k}$. For values of this elasticity greater than two, then $\gamma_{\mathrm{k}}$ will be less than unity. Shown in bold-face are all values of this coefficient that are significantly different from zero at the $90 \%$ level. There are nine such industries, and in eight of the cases, the value of $\gamma_{\mathrm{k}}$ is positive and less than unity. In the one remaining case - for leather products - the value of $\gamma_{\mathrm{k}}$ is negative and of unusually large magnitude. This is an industry where we would not expect differentiated inputs to make a difference, and the negative correlation between product variety and productivity is evidently spurious. In the other eight industries - or one-half of the total set - we would interpret the positive correlation between product variety and productivity as supporting the hypothesis of "semi-endogenous" growth.

Of the eight industries with positive and significant correlations between product variety and productivity, seven of them are within the group of secondary industries, where it seems more likely that "semi-endogenous" growth could apply. The data for these industries appear in Figures 10-18, which we invite the reader to review. The "shifted" value of product variety shown in these figures is the lead or lag that was chosen on the basis of the Akaike information criterion in Table 2. We feel that the visual correlation between productivity and variety (shifted) in these figures is quite remarkable, especially given that the variables are obtained from completely different data sets, so there is no possibility of correlation due to common trends as might arise among macroeconomic variables.

In contrast, Figures 3-9 display the data for the seven primary industries. In some of these industries there is visual evidence of a correlation between product variety and productivity, but

8 For clothing and apparel we use the two-year lag rather than the two-year lead for the regression in Table 3 and following tables, while for electronic products and transportation equipment we use the current value for product variety. 
it is not strong enough to lead to statistical significance. In a number of cases there are also outlying observations for either variety or productivity. For example: textile mill products has an outlying observation for product variety in 1985; wood products in 1989; paper and publishing in 1984; and rubber products has seemingly erratic observations for productivity around 19781980. The outliers for product variety in 1989 can be explained by fact that the classification scheme for U.S. imports changed from the TSUSA to the HS system in that year, so that it was not possible to construct (8) using a common set of goods I over the two years $1988-89 .{ }^{9}$ In other cases, outlying observations for product variety can be explained by slight changes in the names of goods over time, especially in the TSUSA descriptions, making them appear to be different products when in fact they are not. ${ }^{10}$ We have experimented with re-estimating the regressions while excluding these outlying observations, but did not find that the coefficients on product variety were markedly improved.

There are two industries - electrical products and transportation equipment - which we would expect to fit the hypothesis of "semi-endogenous" growth, but for which we do not find any evidence of a correlation between productivity and product variety. It can be seen from Figures 16 and 17 that our product variety measures for these two industries are quite stable as compared to the productivity variables. Perhaps there is too much aggregation within these industries to allow for a meaningful measure of product variety. For example, in the first column of Table 1 we see that Taiwan has much less product variety than Korea in transportation equipment. This is most likely due to the fact that South Korea exports finished automobiles in

\footnotetext{
9 Instead, we have constructed a cross-section product variety index using the common goods between Taiwan and South Korea in 1988, and again in 1989, and take the difference in these to measure (8) for 1988-89.

${ }^{10}$ We have tried to correct some of these classification errors (for example, plastic bags being incorrectly grouped with paper bags), but with over 10,000 TSUSA commodities, it is impossible to track down all such errors.
} 
large quantities, while Taiwan does not export these products at all. ${ }^{11}$ It is precisely this kind of product that is exported by one country and not the other, that will influence that product variety index. But it does not follow that Korea's export of finished automobiles should have a predictable impact on relative productivities across the two countries. In other words, when the product variety measure is constructed over very different products in the two countries, the link between variety and productivity may be lost.

In Table 4, we re-estimate all the industry regression using seemingly unrelated regressions (SUR). By taking account of the correlation of error terms across the sixteen industries, this method allow for a substantial reduction in standard errors, particularly on the product variety coefficients. Thus, in Table 4 all but one of the variety coefficients are significant at the $90 \%$ level. Among the primary industries, these coefficients take on a negative value in three cases and a positive value in three cases. Among the secondary industries, the product variety coefficient is positive in eight out of nine cases, and negative for electrical products; the coefficient on transportation equipment is positive but extremely small. Thus, these results seem to support our overall conclusions that "semi-endogenous" growth works well for nearly all the secondary industries, and gives mixed results for the primary industries.

One potential problem with the regression results in Table 3 and 4 is that the TFP variable can be mismeasured due to the inclusion of super-normal profits in the capital share. As discussed above, a correction for this bias is to include the difference between output growth and capital growth in each industry as an additional regressor in (10), where this variable is treated as

11 In Feenstra, Yang and Hamilton (1997), we construct the product variety index at the five-digit rather than the two-digit SIC level, and only when each five digit industry in South Korea and Taiwan have at least three goods in common. These means that finished automobiles are not included in the product variety calculation, and we find that Korea's higher level of variety within transportation equipment no longer holds. 
endogenous. The coefficient $\delta_{\mathrm{k}}$ on this variable equals $\left(\mu_{\mathrm{k}}-1\right)$, where $\mu_{\mathrm{k}}$ is the price-cost ratio in industry $\mathbf{k}$. In addition, it also seems important to control for the extent of imports and exports in each industry. These are often used explanations for total factor productivity, and we would like to see whether their inclusion has a significant impact on the product variety coefficients. The results from re-estimated the regression for each industry, while including these additional regressors, are shown in Tables 5 and 6.

In Table 5, we measure imports as a share of domestic consumption (equals to production plus imports), and measure exports as a share of domestic production. Both of these are measured as a difference between Taiwan and South Korea, multiplied by 100 . The regressions are estimated with three-stage least squares (3SLS), correcting for the endogeneity of the correction for imperfect competition - the difference between output growth and capital growth in each industry. In the third column of Table 5 we report the coefficient on this variable, which is an estimate of the markup (i.e. the price-cost ratio minus unity). Positive and significant estimates are obtained for eleven out of the sixteen industries (with beverages and tobacco as a borderline case), and negative and significant coefficients are found in three cases. The magnitudes of the markups vary quite a bit across industries, which may be due to the aggregate level of these sectors; Madani $(1996,1997)$ obtains less diverse estimates across 52 industries for South Korea, using more disaggregate data.

In the third and fourth columns of Table 5 we report the coefficients on the import and export shares. These show a surprising degree of variation across industries in both sign and significance. To try and correct this we also considered an alternative measure of trade: the growth rates of imports and exports, expressed in percent and as a difference between Taiwan and Korea. These estimates are shown in Table 6. This alternative trade measure did not lead to 
any improvement in the coefficients of the trade variables themselves, and had only a small impact on the estimated markups and product variety coefficients. The conclusion to is that the inclusion of the trade shares, and the correction for imperfect competition, does not have much of an impact on the coefficients for product variety. These coefficients are reported in the second columns of Tables 5 and 6, and are very similar to what was found in Tables 3 and 4: seven out of the nine secondary industries have positive and significant coefficients, while mixed results are obtained for the primary industries. Thus, our initial OLS results are substantially preserved even after correcting for imperfect competition and various measures of trade.

\section{Conclusions}

Despite the extensive theoretical work on endogenous growth, there have been relatively few attempts to formally test the appropriateness of these models. For the industrial countries, Jones $(1995 \mathrm{a}, \mathrm{b})$ finds that certain predictions of the endogenous growth models do not fit the data. He suggests that a weaker version of the endogenous growth models should be adopted, that does away with certain steady-state growth implications but still relies on the development of new intermediate inputs. The papers in Ito and Krueger (1995) examine the various determinants of growth for the newly-industrialized countries, but primarily at an economy-wide level. This paper is a first attempt to directly test the connection between product variety and productivity at a disaggregate level for two newly-industrialized countries: South Korea and Taiwan. Our interest in these economies is partly motivated by the finding of Feenstra, Yang and Hamilton (1997) that there are differences in the product variety of exports from these countries to the U.S., with Taiwan having a higher level of product variety than Korea in a number of industries. 
At the outset, we divided the sample into primary and secondary industries. This division was intended to capture the degree to which industries would rely on differentiated manufactured inputs. We found that the primary industries do not really support the structure of the "semiendogenous" growth model, and gave mixed results for various industries and estimation methods. For the secondary industries, however, the results provide quite strong support for the "semi-endogenous" growth models. Seven out of the nine industries in this group indicate a positive and significant impact of product variety on productivity. The two exceptions are electrical products and transportation equipment, where the former has a negative (and sometimes significant) impact of variety, and the latter is insignificant. We have explored the sensitivity of our results by including a correction for imperfect competition, as suggested by Hall $(1988,1990)$, and also by including conventional measures of import and export shares. These control variables have only a small influence on the estimated impact of product variety.

As a directions for further research, it would be important to explore whether these results continue to hold over a wider sample of East Asian and other countries. We have computed the cross-sectional product variety index for a number of pairs of East Asian countries. Comparing Hong Kong and Singapore, for example, we find that Hong Kong has greater product variety in its exports to the U.S. than does Singapore in the following sectors: textile mill products; clothing and apparel; paper and printing; leather products; stone, clay and glass products; fabricated metal products; and instruments and misc. Conversely, Singapore has greater product variety in primary metals, while the following sectors do not provide a consistent ranking over the years: chemicals and plastics, rubber products, machinery, and electrical products, and transportation equipment. The result that Hong Kong leads Singapore in product variety for a number of sectors matches the finding of Young (1992), that Hong Kong has rapid 
productivity growth while Singapore has essentially none. Young also stresses that Singapore has moved through the range of products at an unusually rapid rate. It would be interesting indeed to see whether the product variety measures developed here could pick up these dynamic changes in the commodity composition of trade, and serve as an explanation for the contrasting productivity performance of these economies. 


\section{References}

Domowitz, Ian, R. Glenn Hubbard, and Bruce C. Petersen, 1988, "Market Structure and Cyclical Fluctuations in U.S. Manufacturing," Review of Economics and Statistics, 55-66.

Easterly, William, 1995, "Explaining Miracles: Growth Regressions Meet the Gang of Four," in Takatoshi Ito and Anne O. Krueger, eds. Growth Theories in Light of East Asian Experience. NBER and Univ. Of Chicago: Chicago, 267-298.

Feenstra, Robert C., 1994, "New Product Varieties and the Measurement of International Prices," American Economic Review 84(1), March, 157-177.

Feenstra, Robert C., 1996, “NBER Trade Database, Disk 1: U.S. Imports, 1972-1994,” Working Paper no. 5515.

Feenstra, Robert, C. and James Markusen, 1994, "Accounting for Growth with New Inputs," International Economic Review 35(2), May, 429 447.

Feenstra, Robert C., Deng-Shing Huang, and Gary G. Hamilton, 1997, "Business Groups and Trade in East Asia: Part 1, Networked Equilibria,” NBER Working Paper no. 5886.

Feenstra, Robert C., Maria Yang, and Gary G. Hamilton, 1997, "Business Groups and Trade in East Asia: Part 2, Product Variety,” NBER Working Paper no. 5887.

Fukuda, Shin-ichi and Hideki Toya, 1995, "Conditional Convergence in East Asian Countries: The Role of Exports in Economic Growth," in Takatoshi Ito and Anne O. Krueger, eds. Growth Theories in Light of East Asian Experience. NBER and Univ. Of Chicago: Chicago, 247-262.

Grossman, Gene M. and Elhanan Helpman, 1991, Innovation and Growth in the Global Economy. MIT Press: Cambridge, MA.

Jorgenson, Dale W. and Chi-Yuan Liang, 1995, "The Industry-Level Output Growth and Total Factor Productivity Changes in Taiwan, 1961-1993," Department of Economics, Harvard university and Institute of Economics, Academia Sinica, May, mimeo.

Hall, Robert E., 1988, "The Relation between Price and Marginal Cost in U.S. Industry," Journal of Political Economy, 1988 96(5), 921-947.

Hall, Robert E., 1990, "Invariance Properties of Solow's Productivity Residual," in Peter Diamond, ed. Growth/Productivity/Unemployment. MIT Press: Cambridge, MA, $71-112$.

Itoh, Takatoshi and Anne O. Krueger, eds. , 1995, Growth Theories in Light of the East Asian Experience. NBER and Univ. Of Chicago: Chicago. 
Jones, Charles, 1995a, “Time Series Tests of Endogenous Growth Models," Quarterly Journal of Economics 110(2), May, 495-526.

Jones, Charles, 1995b, "R\&D-Based Models of Economic Growth," Journal of Political Economy 103(4), August, 759-784.

Krugman, Paul, 1994, “The Myth of Asia's Miracle," Foreign Affairs, November/December, 62-78.

Liang, Chi-Yuan, 1989, "The Sources of Growth and Productivity Change in Taiwan's Industries, 1961-1981," Discussion Paper, The Institute of Economics, Academia Sinica, Taipei, Taiwan, Republic of China.

Madani, Dorsati , 1996, "Productivity, Markups and Government Policy: Estimates for South Korea, 1972-1991," University of California, Davis, November, mimeo.

Madani, Dorsati , 1997, "Imperfect Competition, Economies of Scale and the Impact of Government Policies on Productivity: South Korea and Taiwan, 1972-1991," Ph.D. dissertation, University of California, Davis.

Mankiw, Gregory N., David Romer and David N. Weil, 1992, "A Contribution to the Empirics of Economic Growth" Quarterly Journal of Economics 107(2), May, 407-437.

Romer, Paul, 1990, "Endogenous Technological Change," Journal of Political Economy 98(5), pt. 2, October, S71-S102.

Sato, Kazuo, 1976, "The Ideal Log-Change Index Number," Review of Economics and Statistics 58(2), May, 223-228.

Vartia, Yrjo O., 1976, “Ideal Log-Change Index Numbers," Scandinavian Journal of Statistics $3(3), 121-126$.

The World Bank, 1993, The East Asian Miracle: Economic Growth and Public Policy, Washington, D.C.

Young, Alwyn, 1992, "A Tale of Two Cities: Factor Accumulation and Technical Change in Hong Kong and Singapore," in Olivier Blanchard and Stanley Fischer, eds. NBER Macroeconomics Annual, 1992. MIT Press: Cambridge, MA, 13-53.

Ziele, William, 1993, "Industrial Targeting, Business Organization and Industry Productivity Growth in the Republic of Korea, 1972-1985," Ph.D. dissertation, University of California, Davis. 


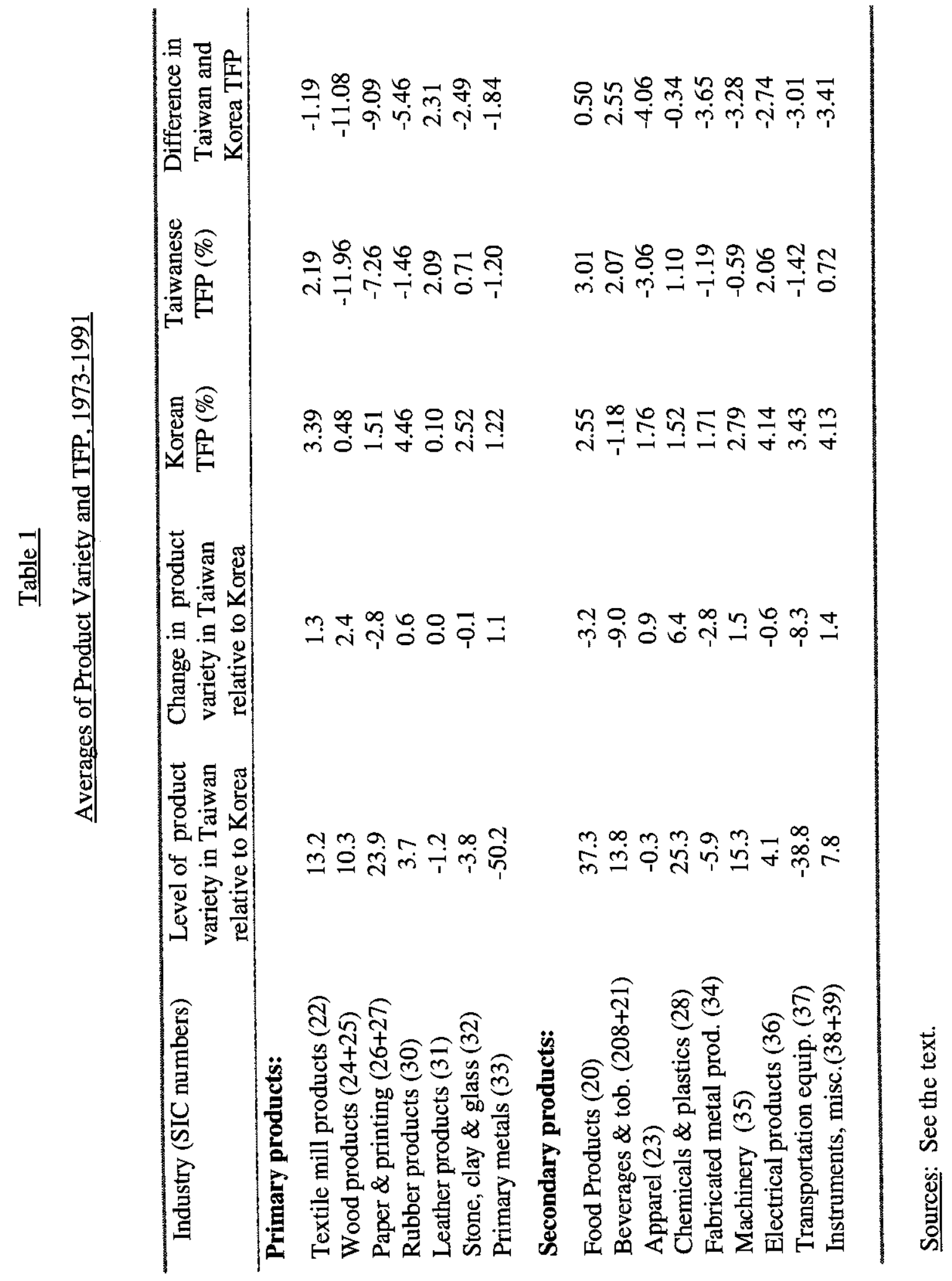




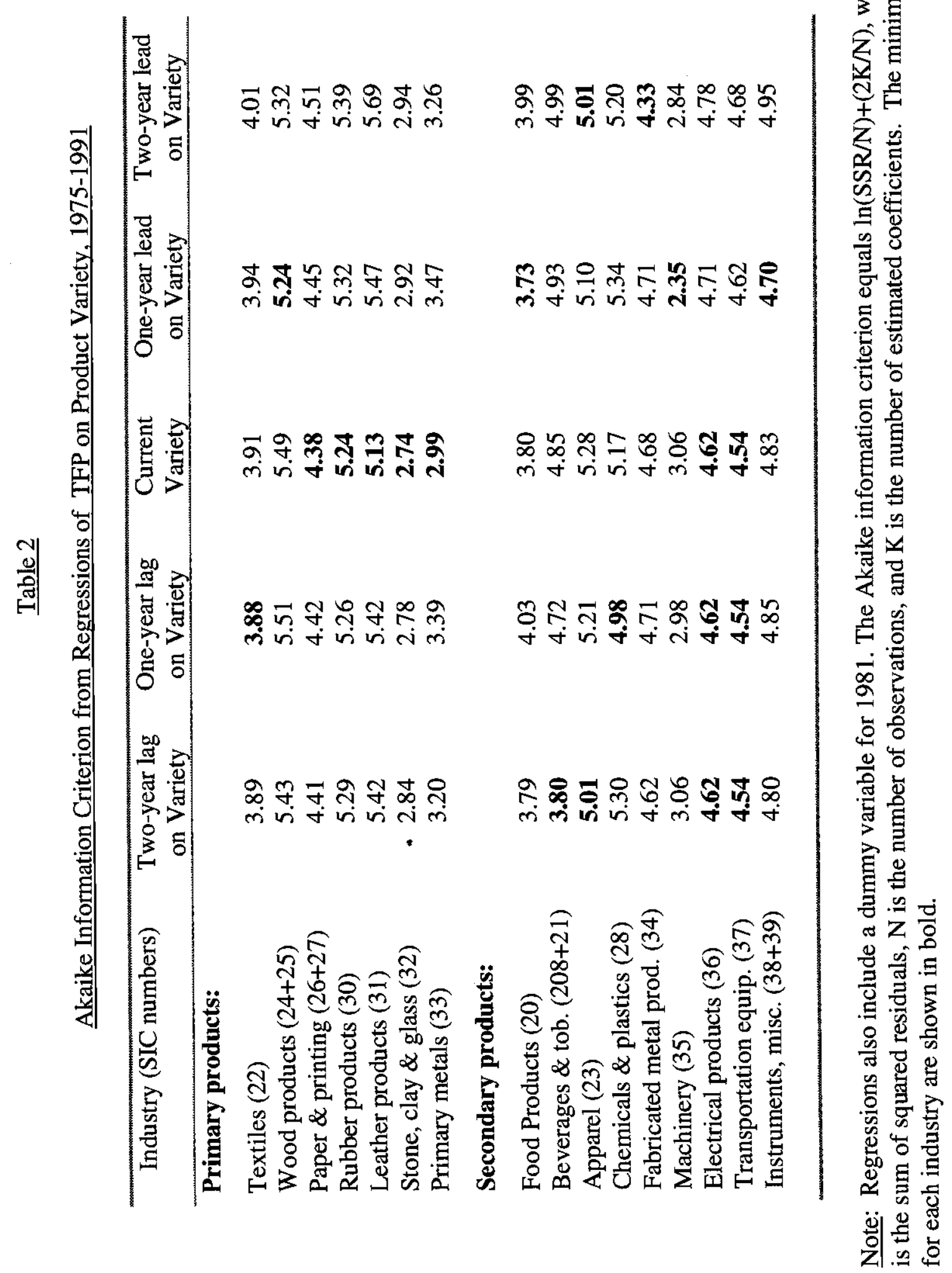


Table 3

$\underline{\text { Regressions of TFP on Product Variety, 1975-1991 }}$

\begin{tabular}{|c|c|c|c|c|c|}
\hline Industry (SIC numbers) & Constant & $\begin{array}{l}\text { Product } \\
\text { Variety }\end{array}$ & $\begin{array}{l}\text { Year } \\
1981\end{array}$ & $\begin{array}{l}\text { Durbin } \\
\text { Watson }\end{array}$ & $\mathrm{R}^{2}, \mathrm{~N}$ \\
\hline \multicolumn{6}{|l|}{ Primary Products: } \\
\hline Textile mill products (22) & $\begin{array}{c}-0.09 \\
(-0.05)\end{array}$ & $\begin{array}{c}-0.04 \\
(-0.63)\end{array}$ & $\begin{array}{l}-19.16 \\
(-2.86)\end{array}$ & 2.00 & $0.37,17$ \\
\hline Wood products $(24+25)$ & $\begin{array}{l}-10.06 \\
(-2.85)\end{array}$ & $\begin{array}{c}0.06 \\
(0.13)\end{array}$ & $\begin{array}{c}-4.20 \\
(-0.32)\end{array}$ & 1.33 & $0.01,16$ \\
\hline Paper \& printing $(26+27)$ & $\begin{array}{c}-5.06 \\
(-2.22)\end{array}$ & $\begin{array}{c}-0.40 \\
(-1.26)\end{array}$ & $\begin{array}{c}-3.83 \\
(-0.44)\end{array}$ & 1.94 & $0.13,17$ \\
\hline Rubber products (30) & $\begin{array}{c}-4.88 \\
(-1.50)\end{array}$ & $\begin{array}{c}0.29 \\
(0.90)\end{array}$ & $\begin{array}{l}-26.61 \\
(-2.01)\end{array}$ & 0.71 & $0.28,17$ \\
\hline Leather products (31) & $\begin{array}{c}5.44 \\
(1.80)\end{array}$ & $\begin{array}{c}-2.77 \\
(-2.23)\end{array}$ & $\begin{array}{l}-27.97 \\
(-2.16)\end{array}$ & 2.23 & $0.49,17$ \\
\hline Stone, clay \& glass (32) & $\begin{array}{c}-0.14 \\
(-0.16)\end{array}$ & $\begin{array}{c}0.15 \\
(1.32)\end{array}$ & $\begin{array}{l}-15.56 \\
(-3.81)\end{array}$ & 2.53 & $0.51,17$ \\
\hline Primary metals (33) & $\begin{array}{c}1.15 \\
(1.11)\end{array}$ & $\begin{array}{c}0.11 \\
(2.74)\end{array}$ & $\begin{array}{l}-15.59 \\
(-3.66)\end{array}$ & 2.76 & $0.61,17$ \\
\hline \multicolumn{6}{|l|}{ Secondary products: } \\
\hline Food Products (20) & $\begin{array}{c}2.15 \\
(1.26)\end{array}$ & $\begin{array}{c}0.22 \\
(2.45)\end{array}$ & $\begin{array}{l}-21.26 \\
(-3.13)\end{array}$ & 1.67 & $0.47,16$ \\
\hline Beverages \& tob. $(208+21)$ & $\begin{array}{c}6.22 \\
(3.95)\end{array}$ & $\begin{array}{c}0.22 \\
(5.19)\end{array}$ & $\begin{array}{c}0.30 \\
(0.04)\end{array}$ & 2.29 & $0.67,17$ \\
\hline Apparel (23) & $\begin{array}{c}-2.87 \\
(-1.01)\end{array}$ & $\begin{array}{c}0.77 \\
(2.24)\end{array}$ & $\begin{array}{c}1.52 \\
(0.13)\end{array}$ & 1.65 & $0.27,17$ \\
\hline Chemicals \& plastic (28) & $\begin{array}{c}1.89 \\
(0.67)\end{array}$ & $\begin{array}{c}0.20 \\
(2.31)\end{array}$ & $\begin{array}{l}-15.81 \\
(-1.37)\end{array}$ & 3.13 & $0.32,17$ \\
\hline Metal products (34) & $\begin{array}{c}-2.38 \\
(-1.11)\end{array}$ & $\begin{array}{c}0.27 \\
(2.41)\end{array}$ & $\begin{array}{l}-20.53 \\
(-2.02)\end{array}$ & 2.02 & $0.66,15$ \\
\hline Machinery (35) & $\begin{array}{c}-1.76 \\
(-2.28)\end{array}$ & $\begin{array}{c}0.16 \\
(2.96)\end{array}$ & $\begin{array}{c}4.56 \\
(1.48)\end{array}$ & 2.24 & $0.44,16$ \\
\hline Electrical products (36) & $\begin{array}{c}-1.03 \\
(-0.44)\end{array}$ & $\begin{array}{c}-0.17 \\
(-0.48)\end{array}$ & $\begin{array}{l}-24.66 \\
(-2.47)\end{array}$ & 1.97 & $0.35,17$ \\
\hline Transportation equip. (37) & $\begin{array}{c}-0.71 \\
(-0.31)\end{array}$ & $\begin{array}{l}0.008 \\
(0.30)\end{array}$ & $\begin{array}{l}-41.94 \\
(-4.51)\end{array}$ & 2.02 & $0.59,17$ \\
\hline Instruments, misc. $(38+39)$ & $\begin{array}{c}-2.32 \\
(-0.92)\end{array}$ & $\begin{array}{c}0.76 \\
(1.82)\end{array}$ & $\begin{array}{l}-15.76 \\
(-1.56)\end{array}$ & 1.85 & $0.28,16$ \\
\hline
\end{tabular}

Note: $\mathrm{T}$-statistics are in parentheses, and coefficients on product variety that are significant at the $90 \%$ level are in bold. 
Table 4

SUR Regressions of TFP on Product Variety, 1975-1991

\begin{tabular}{|c|c|c|c|c|c|}
\hline Industry (SIC numbers) & Constant & $\begin{array}{l}\text { Product } \\
\text { Variety }\end{array}$ & $\begin{array}{l}\text { Year } \\
1981\end{array}$ & $\begin{array}{l}\text { Durbin } \\
\text { Watson }\end{array}$ & $\mathbf{R}^{2}, \mathrm{~N}$ \\
\hline \multicolumn{6}{|l|}{ Primary products: } \\
\hline Textiles (22) & $\begin{array}{c}-0.08 \\
(-0.19)\end{array}$ & $\begin{array}{c}-0.04 \\
(-3.97)\end{array}$ & $\begin{array}{l}-19.18 \\
(-3.25)\end{array}$ & 2.00 & $0.37,17$ \\
\hline Wood products $(24+25)$ & $\begin{array}{l}-10.29 \\
(-2.91)\end{array}$ & $\begin{array}{c}0.21 \\
(0.97)\end{array}$ & $\begin{array}{c}-6.67 \\
(-0.57)\end{array}$ & 1.35 & $-0.04,16$ \\
\hline Paper \& printing $(26+27)$ & $\begin{array}{c}-4.62 \\
(-2.24)\end{array}$ & $\begin{array}{c}-0.27 \\
(-2.62)\end{array}$ & $\begin{array}{c}-5.16 \\
(-0.67)\end{array}$ & 1.95 & $0.11,17$ \\
\hline Rubber products (30) & $\begin{array}{c}-4.79 \\
(-1.83)\end{array}$ & $\begin{array}{c}0.26 \\
(4.28)\end{array}$ & $\begin{array}{l}-27.26 \\
(-2.32)\end{array}$ & 0.71 & $0.28,17$ \\
\hline Leather products ( 31 ) & $\begin{array}{c}5.45 \\
(2.34)\end{array}$ & $\begin{array}{c}-2.89 \\
(-7.91)\end{array}$ & $\begin{array}{l}-28.33 \\
(-2.53)\end{array}$ & 2.25 & $0.49,17$ \\
\hline Stone, clay \& glass (32) & $\begin{array}{c}-0.12 \\
(-0.26)\end{array}$ & $\begin{array}{c}0.15 \\
(4.93)\end{array}$ & $\begin{array}{l}-16.01 \\
(-4.70)\end{array}$ & 2.49 & $0.50,17$ \\
\hline Primary metals (33) & $\begin{array}{c}1.18 \\
(1.50)\end{array}$ & $\begin{array}{c}\mathbf{0 . 1 2} \\
(7.31)\end{array}$ & $\begin{array}{l}-15.73 \\
(-4.12)\end{array}$ & 2.74 & $0.61,17$ \\
\hline \multicolumn{6}{|l|}{ Secondary products: } \\
\hline Food Products (20) & $\begin{array}{c}2.12 \\
(1.81)\end{array}$ & $\begin{array}{c}0.22 \\
(6.73)\end{array}$ & $\begin{array}{l}-21.06 \\
(-3.80)\end{array}$ & 1.67 & $0.47,16$ \\
\hline Beverages \& tob. $(208+21)$ & $\begin{array}{c}6.20 \\
(5.15)\end{array}$ & $\begin{array}{c}0.21 \\
(16.62)\end{array}$ & $\begin{array}{c}-0.45 \\
(-0.08)\end{array}$ & 2.27 & $0.67,17$ \\
\hline Apparel (23) & $\begin{array}{c}-2.85 \\
(-1.19)\end{array}$ & $\begin{array}{c}\mathbf{0 . 7 6} \\
(7.37)\end{array}$ & $\begin{array}{c}1.31 \\
(0.12)\end{array}$ & 1.67 & $0.27,17$ \\
\hline Chemicals \& plastic (28) & $\begin{array}{c}1.93 \\
(0.98)\end{array}$ & $\begin{array}{c}0.18 \\
(10.66)\end{array}$ & $\begin{array}{l}-16.44 \\
(-1.58)\end{array}$ & 3.13 & $0.32,17$ \\
\hline Metal products (34) & $\begin{array}{c}-2.40 \\
(-1.88)\end{array}$ & $\begin{array}{c}0.27 \\
(5.82)\end{array}$ & $\begin{array}{l}-20.32 \\
(-2.69)\end{array}$ & 2.03 & $0.66,15$ \\
\hline Machinery (35) & $\begin{array}{c}-1.73 \\
(-2.51)\end{array}$ & $\begin{array}{c}0.17 \\
(10.69)\end{array}$ & $\begin{array}{c}4.01 \\
(1.47)\end{array}$ & 2.18 & $0.44,16$ \\
\hline Electronic products (36) & $\begin{array}{c}-1.01 \\
(-0.31)\end{array}$ & $\begin{array}{c}-0.16 \\
(-2.02)\end{array}$ & $\begin{array}{l}-25.09 \\
(-2.89)\end{array}$ & 1.98 & $0.35,17$ \\
\hline Transportation equip. (37) & $\begin{array}{c}-0.69 \\
(-0.26)\end{array}$ & $\begin{array}{l}0.008 \\
(2.25)\end{array}$ & $\begin{array}{l}-42.21 \\
(-5.07)\end{array}$ & 2.01 & $0.59,17$ \\
\hline Instruments, misc. $(38+39)$ & $\begin{array}{c}-2.31 \\
(-1.39)\end{array}$ & $\begin{array}{c}0.74 \\
(4.42)\end{array}$ & $\begin{array}{l}-15.47 \\
(-1.74)\end{array}$ & 1.84 & $0.28,16$ \\
\hline
\end{tabular}

Note: T-statistics are in parentheses, and coefficients on product variety that are significant at the $90 \%$ level are in bold. 
Table 5

Dependent Variable: Total Factor Productivity, 1975-1991

\begin{tabular}{|c|c|c|c|c|c|}
\hline Industry (SIC numbers) & $\begin{array}{l}\text { Product } \\
\text { Variety }\end{array}$ & $\begin{array}{l}\text { Imperfect } \\
\text { Competition }\end{array}$ & $\begin{array}{l}\text { Import } \\
\text { Share }\end{array}$ & $\begin{array}{l}\text { Export } \\
\text { Share }\end{array}$ & $\mathrm{R}^{2}, \mathrm{~N}$ \\
\hline \multicolumn{6}{|l|}{ Primary Products: } \\
\hline Textile mill products $(22)$ & $\begin{array}{c}-0.04 \\
(-2.41)\end{array}$ & $\begin{array}{c}0.59 \\
(7.14)\end{array}$ & $\begin{array}{l}-0.02 \\
(-0.03)\end{array}$ & $\begin{array}{c}0.86 \\
(3.49)\end{array}$ & $0.77,17$ \\
\hline Wood products $(24+25)$ & $\begin{array}{l}-0.10 \\
(-0.61)\end{array}$ & $\begin{array}{l}-0.38 \\
(-4.09)\end{array}$ & $\begin{array}{c}4.02 \\
(2.65)\end{array}$ & $\begin{array}{c}1.39 \\
(5.28)\end{array}$ & $0.32,16$ \\
\hline Paper \& printing $(26+27)$ & $\begin{array}{l}-0.20 \\
(-1.42)\end{array}$ & $\begin{array}{c}-0.16 \\
(-1.21)\end{array}$ & $\begin{array}{l}1.27 \\
(3.20)\end{array}$ & $\begin{array}{l}-1.58 \\
(-3.38)\end{array}$ & $0.23,17$ \\
\hline Rubber products (30) & $\begin{array}{l}-0.24 \\
(3.81)\end{array}$ & $\begin{array}{c}0.53 \\
(10.67)\end{array}$ & $\begin{array}{l}-3.37 \\
(-8.77)\end{array}$ & $\begin{array}{c}1.13 \\
(5.67)\end{array}$ & $0.79,17$ \\
\hline Leather products (31) & $\begin{array}{c}-2.37 \\
(-5.96)\end{array}$ & $\begin{array}{c}0.27 \\
(3.14)\end{array}$ & $\begin{array}{c}0.00 \\
(0.00)\end{array}$ & $\begin{array}{l}-0.09 \\
(-0.89)\end{array}$ & $0.60,17$ \\
\hline Stone, clay \& glass (32) & $\begin{array}{c}0.17 \\
(4.90)\end{array}$ & $\begin{array}{c}0.27 \\
(4.23)\end{array}$ & $\begin{array}{l}-0.78 \\
(-3.10)\end{array}$ & $\begin{array}{c}0.10 \\
(1.88)\end{array}$ & $0.66,17$ \\
\hline Primary metals (33) & $\begin{array}{c}0.02 \\
(0.91)\end{array}$ & $\begin{array}{c}0.31 \\
(5.13)\end{array}$ & $\begin{array}{l}-0.24 \\
(-2.17)\end{array}$ & $\begin{array}{c}0.18 \\
(2.56)\end{array}$ & $0.77,17$ \\
\hline Secondary products: & & & & & \\
\hline Food Products (20) & $\begin{array}{c}0.19 \\
(4.85)\end{array}$ & $\begin{array}{c}-0.36 \\
(-3.56)\end{array}$ & $\begin{array}{c}1.48 \\
(5.45)\end{array}$ & $\begin{array}{l}-0.13 \\
(-1.37)\end{array}$ & $0.67,16$ \\
\hline Beverages \& tob. $(208+21)$ & $\begin{array}{c}0.21 \\
(14.26)\end{array}$ & $\begin{array}{c}0.06 \\
(1.62)\end{array}$ & $\begin{array}{c}0.36 \\
(0.92)\end{array}$ & $\begin{array}{c}0.98 \\
(3.62)\end{array}$ & $0.77,17$ \\
\hline Apparel (23) & $\begin{array}{c}1.09 \\
(10.06)\end{array}$ & $\begin{array}{c}0.42 \\
(2.91)\end{array}$ & $\begin{array}{c}-0.72 \\
(-0.83)\end{array}$ & $\begin{array}{l}-0.20 \\
(-2.14)\end{array}$ & $0.51,17$ \\
\hline Chemicals \& plastics (28) & $\begin{array}{c}0.09 \\
(3.44)\end{array}$ & $\begin{array}{c}0.82 \\
(10.82)\end{array}$ & $\begin{array}{l}-1.15 \\
(-3.47)\end{array}$ & $\begin{array}{c}-0.14 \\
(-0.29)\end{array}$ & $0.80,17$ \\
\hline Fabricated metal prod. (34) & $\begin{array}{c}\mathbf{0 . 2 5} \\
(\mathbf{5 . 8 2})\end{array}$ & $\begin{array}{c}0.20 \\
(2.31)\end{array}$ & $\begin{array}{l}-0.39 \\
(-1.11)\end{array}$ & $\begin{array}{c}0.09 \\
(0.80)\end{array}$ & $0.74,15$ \\
\hline Machinery (35) & $\begin{array}{c}\mathbf{0 . 1 7} \\
(\mathbf{8 . 6 7})\end{array}$ & $\begin{array}{c}0.09 \\
(3.22)\end{array}$ & $\begin{array}{c}0.05 \\
(0.66)\end{array}$ & $\begin{array}{c}0.34 \\
(1.97)\end{array}$ & $0.54,16$ \\
\hline Electrical products (36) & $\begin{array}{c}-0.49 \\
(-2.15)\end{array}$ & $\begin{array}{c}-0.19 \\
(-1.83)\end{array}$ & $\begin{array}{c}1.24 \\
(2.15)\end{array}$ & $\begin{array}{c}-0.78 \\
(-2.91)\end{array}$ & $0.32,17$ \\
\hline Transportation equip. (37) & $\begin{array}{c}0.01 \\
(1.27)\end{array}$ & $\begin{array}{c}0.49 \\
(6.32)\end{array}$ & $\begin{array}{c}0.07 \\
(0.44)\end{array}$ & $\begin{array}{l}-0.20 \\
(1.94)\end{array}$ & $0.74,17$ \\
\hline Instruments, misc. $(38+39)$ & $\begin{array}{c}0.51 \\
(2.74)\end{array}$ & $\begin{array}{c}0.32 \\
(2.42)\end{array}$ & $\begin{array}{c}0.03 \\
(0.11)\end{array}$ & $\begin{array}{c}-0.32 \\
(-3.00)\end{array}$ & $0.20,16$ \\
\hline
\end{tabular}

Note: T-statistics are in parentheses, and coefficients on product variety that are significant at the $90 \%$ level are in bold. The regressions also include a constant term and year-dummy for 1981 , which are not reported. Estimation is performed with 3SLS, using instruments to correct for endogeneity of the imperfect competition term (see the main text). 
Table 6

Dependent Variable: Total Factor Productivity, 1975-1991

\begin{tabular}{|c|c|c|c|c|c|}
\hline Industry (SIC numbers) & $\begin{array}{l}\text { Product } \\
\text { Variety }\end{array}$ & $\begin{array}{c}\text { Imperfect } \\
\text { Competition }\end{array}$ & $\begin{array}{l}\text { Import } \\
\text { Growth }\end{array}$ & $\begin{array}{l}\text { Export } \\
\text { Growth }\end{array}$ & $\mathrm{R}^{2}, \mathrm{~N}$ \\
\hline \multicolumn{6}{|l|}{ Primary Products: } \\
\hline Textile mill products (22) & $\begin{array}{c}-0.06 \\
(-3.61)\end{array}$ & $\begin{array}{c}0.46 \\
(9.17)\end{array}$ & $\begin{array}{c}-0.09 \\
(-1.50)\end{array}$ & $\begin{array}{c}-0.12 \\
(-2.36)\end{array}$ & $0.79,17$ \\
\hline Wood products $(24+25)$ & $\begin{array}{c}0.02 \\
(0.08)\end{array}$ & $\begin{array}{c}-0.04 \\
(-0.34)\end{array}$ & $\begin{array}{c}0.24 \\
(2.71)\end{array}$ & $\begin{array}{c}0.11 \\
(1.26)\end{array}$ & $0.15,16$ \\
\hline Paper \& printing $(26+27)$ & $\begin{array}{c}-0.18 \\
(-1.31)\end{array}$ & $\begin{array}{c}0.14 \\
(1.34)\end{array}$ & $\begin{array}{c}-0.11 \\
(-1.94)\end{array}$ & $\begin{array}{c}0.19 \\
(3.19)\end{array}$ & $0.26,17$ \\
\hline Rubber products (30) & $\begin{array}{c}0.17 \\
(2.00)\end{array}$ & $\begin{array}{c}0.55 \\
(7.65)\end{array}$ & $\begin{array}{c}0.19 \\
(2.83)\end{array}$ & $\begin{array}{c}0.07 \\
(1.07)\end{array}$ & $0.62,17$ \\
\hline Leather products (31) & $\begin{array}{c}-2.66 \\
(-7.19)\end{array}$ & $\begin{array}{c}0.35 \\
(4.01)\end{array}$ & $\begin{array}{l}-0.005 \\
(-0.33)\end{array}$ & $\begin{array}{l}0.004 \\
(0.13)\end{array}$ & $0.61,17$ \\
\hline Stone, clay \& glass (32) & $\begin{array}{c}0.28 \\
(5.29)\end{array}$ & $\begin{array}{c}0.07 \\
(1.17)\end{array}$ & $\begin{array}{c}-0.05 \\
(-3.01)\end{array}$ & $\begin{array}{c}-0.08 \\
(-3.47)\end{array}$ & $0.66,17$ \\
\hline Primary metals (33) & $\begin{array}{c}-0.08 \\
(-2.26)\end{array}$ & $\begin{array}{c}0.59 \\
(5.55)\end{array}$ & $\begin{array}{c}0.05 \\
(2.25)\end{array}$ & $\begin{array}{c}0.26 \\
(4.33)\end{array}$ & $0.75,17$ \\
\hline \multicolumn{6}{|l|}{ Secondary products: } \\
\hline Food Products (20) & $\begin{array}{c}\mathbf{0 . 1 2} \\
(\mathbf{2 . 3 3})\end{array}$ & $\begin{array}{c}0.33 \\
(1.58)\end{array}$ & $\begin{array}{c}0.08 \\
(2.03)\end{array}$ & $\begin{array}{c}0.18 \\
(3.79)\end{array}$ & $0.69,16$ \\
\hline Beverages \& tob. $(208+21)$ & $\begin{array}{c}0.18 \\
(10.88)\end{array}$ & $\begin{array}{c}0.05 \\
(0.82)\end{array}$ & $\begin{array}{c}0.06 \\
(1.57)\end{array}$ & $\begin{array}{c}0.02 \\
(1.15)\end{array}$ & $0.75,17$ \\
\hline Apparel (23) & $\begin{array}{c}2.09 \\
(11.63)\end{array}$ & $\begin{array}{c}0.91 \\
(7.53)\end{array}$ & $\begin{array}{c}0.07 \\
(4.67)\end{array}$ & $\begin{array}{c}-0.33 \\
(-7.40)\end{array}$ & $0.64,17$ \\
\hline Chemicals \& plastics (28) & $\begin{array}{c}0.18 \\
(6.96)\end{array}$ & $\begin{array}{c}0.58 \\
(10.12)\end{array}$ & $\begin{array}{c}0.12 \\
(4.00)\end{array}$ & $\begin{array}{c}-0.02 \\
(-0.36)\end{array}$ & $0.83,17$ \\
\hline Fabricated metal prod. (34) & $\begin{array}{c}0.29 \\
(5.65)\end{array}$ & $\begin{array}{c}0.23 \\
(2.74)\end{array}$ & $\begin{array}{c}-0.01 \\
(-0.22)\end{array}$ & $\begin{array}{c}-0.01 \\
(-0.24)\end{array}$ & $0.73,15$ \\
\hline Machinery (35) & $\begin{array}{c}0.17 \\
(6.39)\end{array}$ & $\begin{array}{c}0.09 \\
(2.05)\end{array}$ & $\begin{array}{c}0.03 \\
(1.79)\end{array}$ & $\begin{array}{c}-0.04 \\
(-1.11)\end{array}$ & $0.51,16$ \\
\hline Electrical products (36) & $\begin{array}{c}-0.24 \\
(-1.07)\end{array}$ & $\begin{array}{c}-0.04 \\
(-0.30)\end{array}$ & $\begin{array}{c}0.11 \\
(0.87)\end{array}$ & $\begin{array}{c}0.05 \\
(0.35)\end{array}$ & $0.40,17$ \\
\hline Transportation equip. (37) & $\begin{array}{c}0.01 \\
(1.30)\end{array}$ & $\begin{array}{c}0.42 \\
(4.57)\end{array}$ & $\begin{array}{l}-0.003 \\
(-0.09)\end{array}$ & $\begin{array}{c}-0.06 \\
(-2.03)\end{array}$ & $0.74,17$ \\
\hline Instruments, misc. $(38+39)$ & $\begin{array}{c}0.55 \\
(3.65)\end{array}$ & $\begin{array}{c}-0.55 \\
(-2.91)\end{array}$ & $\begin{array}{c}-0.01 \\
(-0.20)\end{array}$ & $\begin{array}{c}0.45 \\
(4.49)\end{array}$ & $0.48,16$ \\
\hline
\end{tabular}

Note: T-statistics are in parentheses, and coefficients on product variety that are significant at the 90\% level are in bold. The regressions also include a constant term and year-dummy for 1981, which are not reported. Estimation is performed with 3SLS, using instruments to correct for endogeneity of the imperfect competition term (see the main text). 


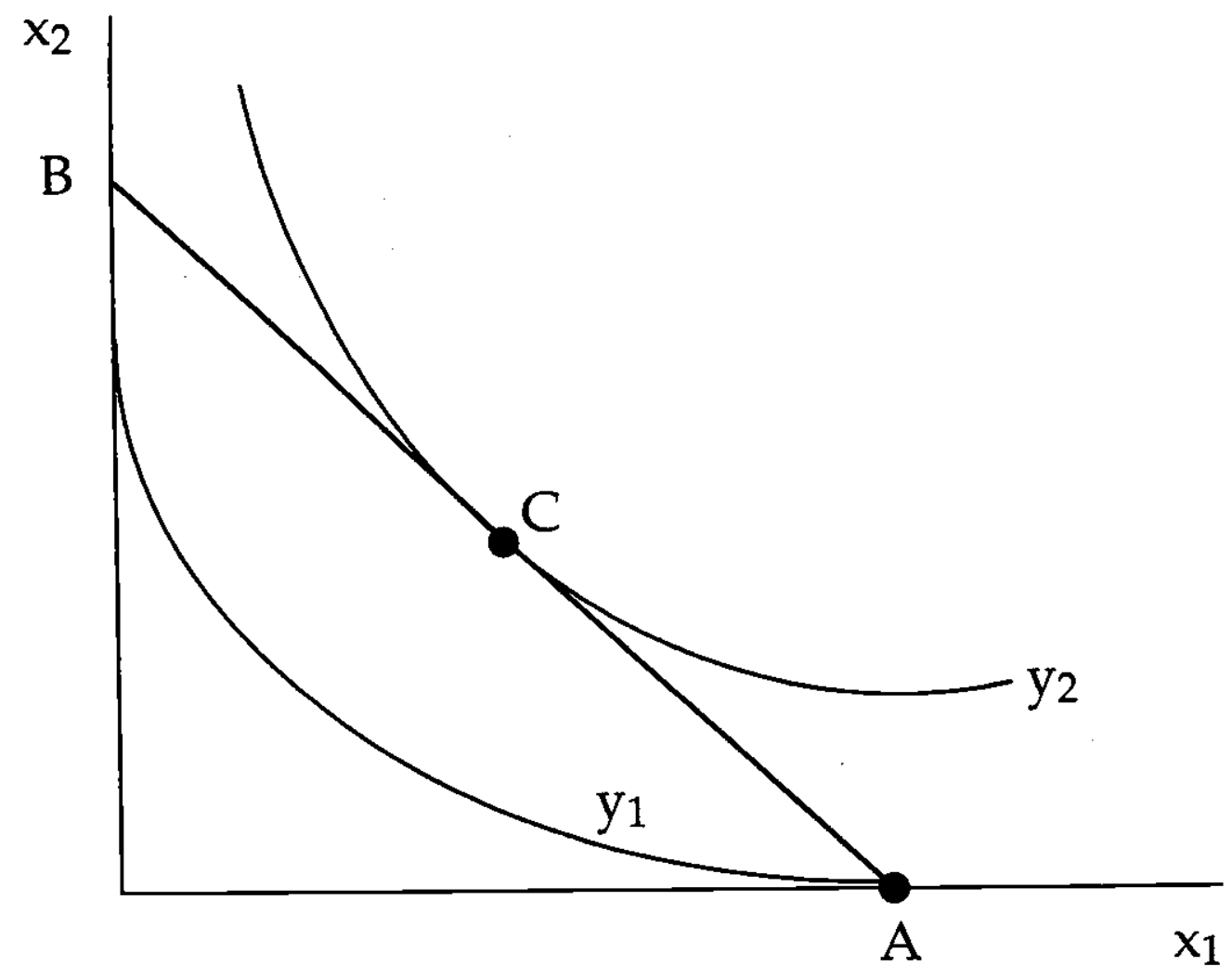

Figure 1

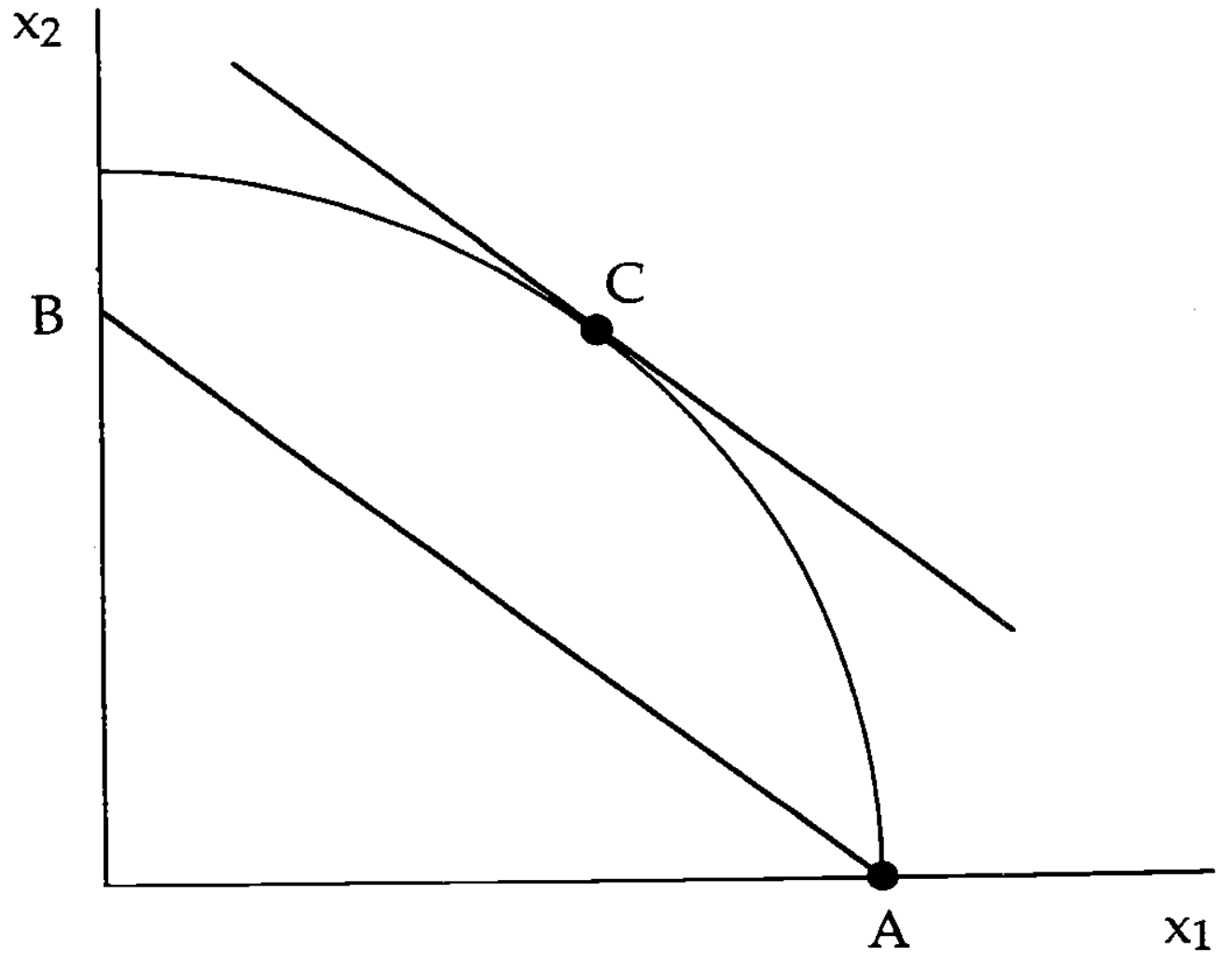

Figure 2 

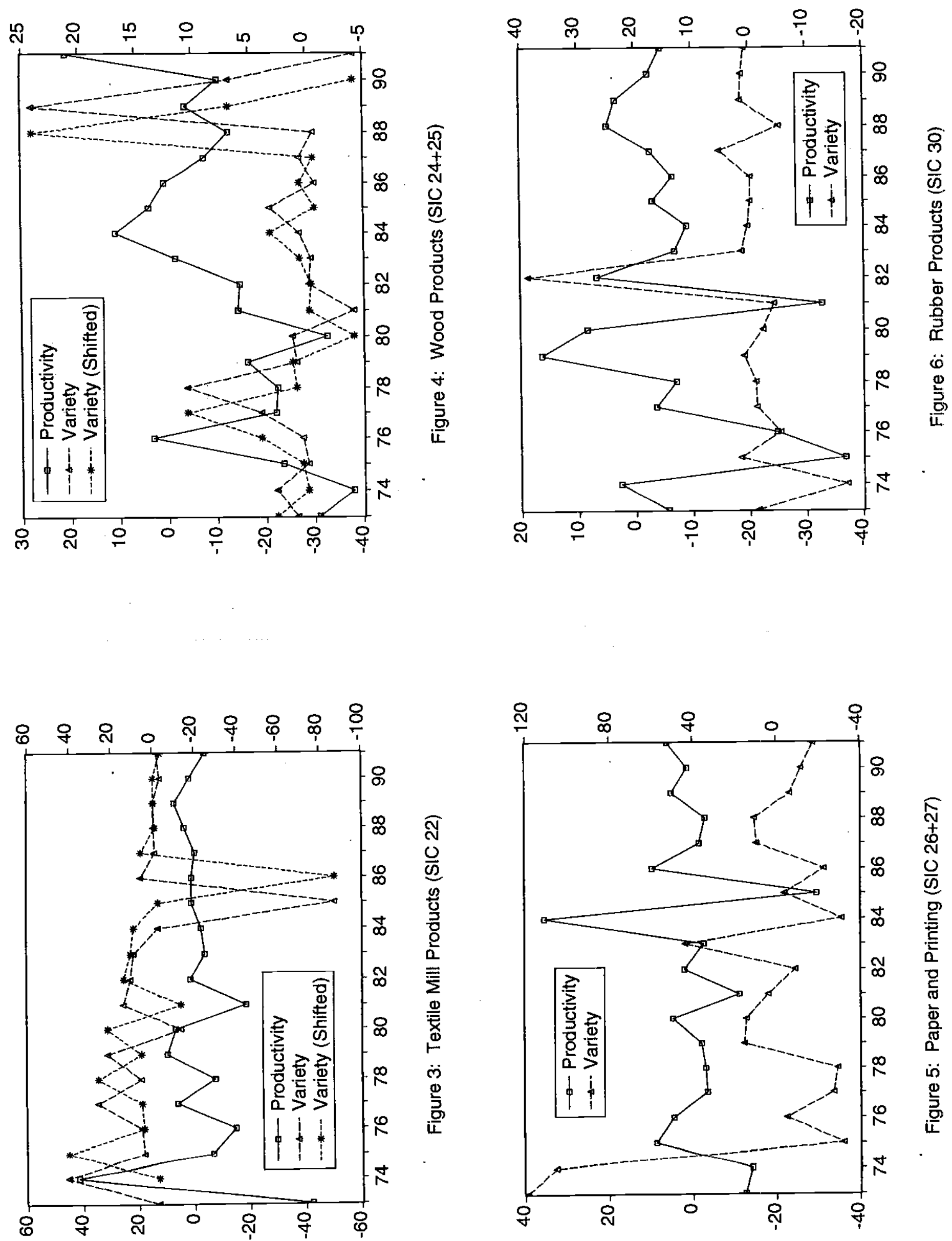

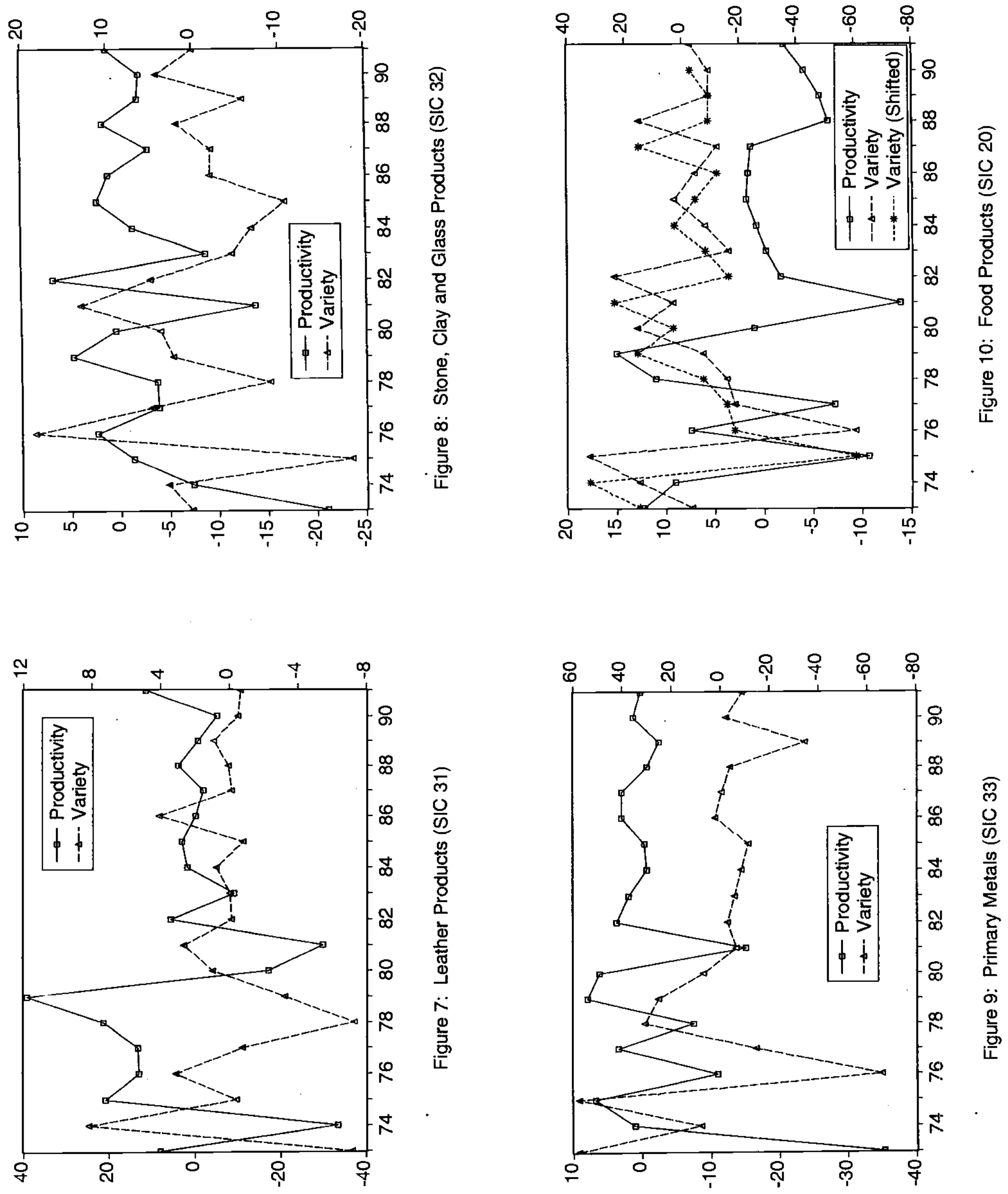

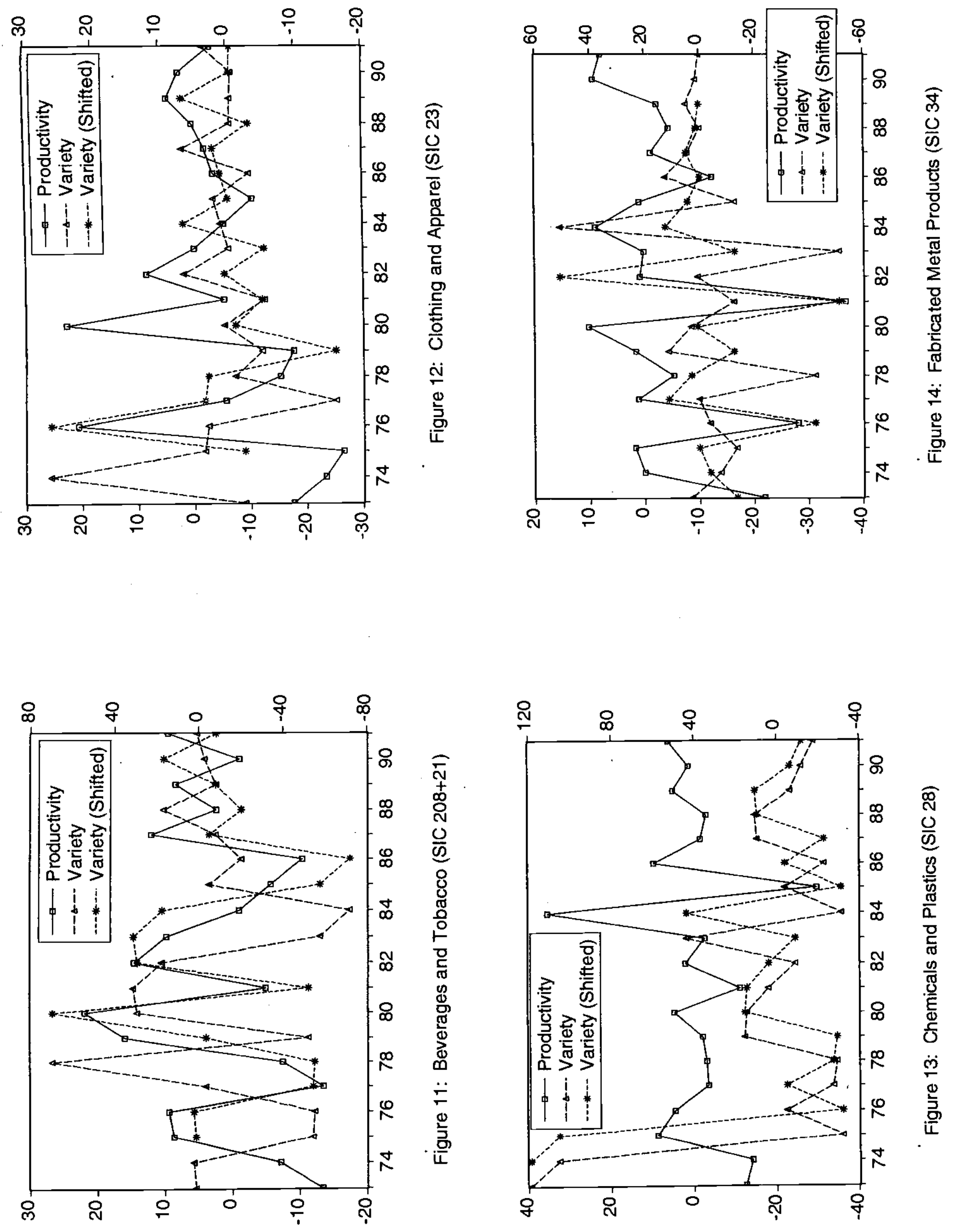

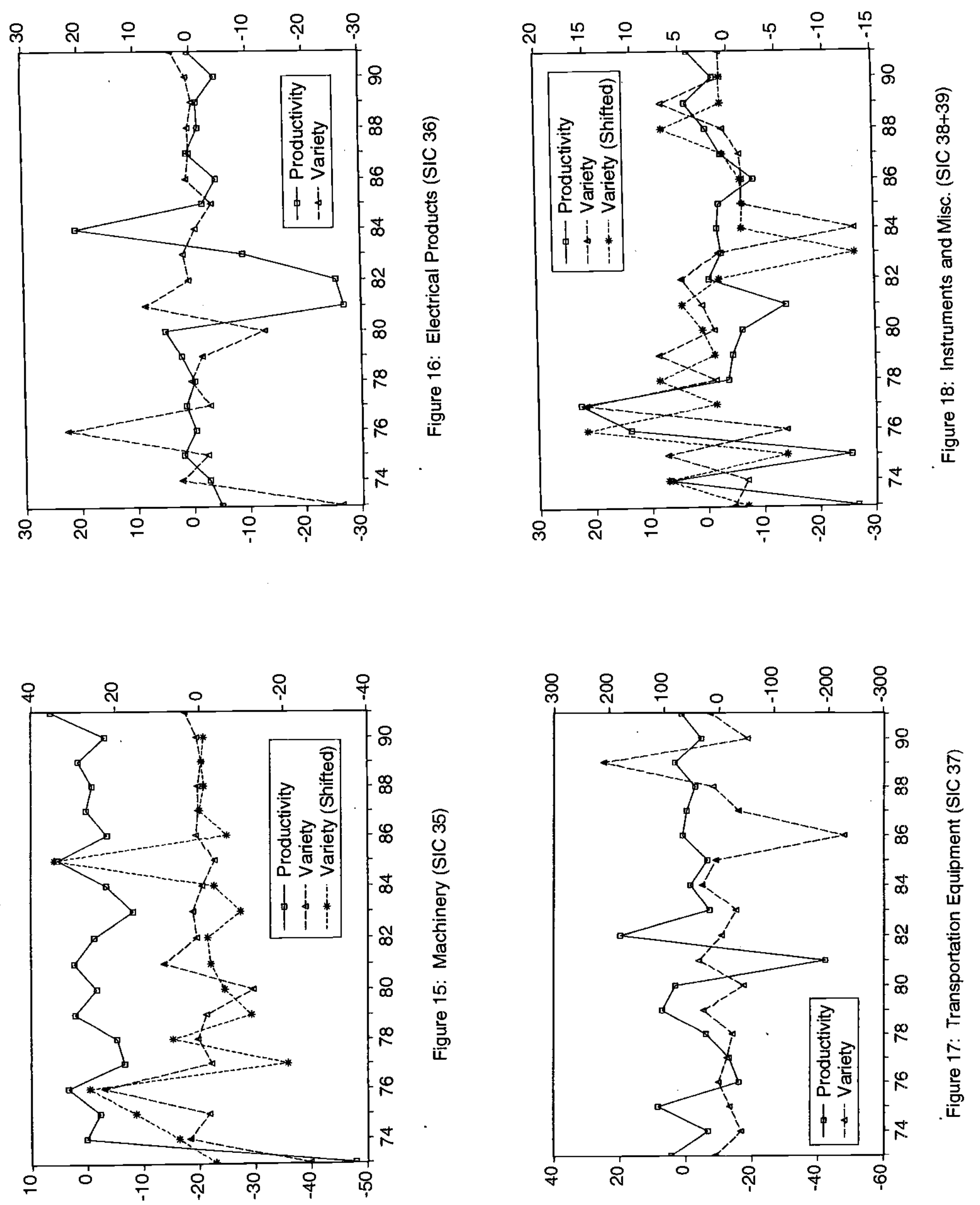